\title{
Challenges Faced by ASHAs during their Field Works: A Cross Sectional Observational Study in Rural Area of Jaipur, Rajasthan
}

\author{
Sadhana Meena', Monika Rathore ${ }^{1}$, Pragya Kumawat ${ }^{1, *}$, Arpit Singh ${ }^{2}$
}

\section{Sadhana Meena', Monika Rathore', Pragya Kumawat ${ }^{1, *}$, Arpit Singh ${ }^{2}$ \\ 'Department of Community Medicine, SMS Medical College, Jaipur, Rajasthan, INDIA. \\ ${ }^{2}$ Department of Orthopedics, KGMU,} Lucknow, Uttar Pradesh, INDIA.

\section{Correspondence}

\section{Dr. Pragya Kumawat,}

Department of Community Medicine, SMS Medical College, Malviya Nagar, Jaipur-302017, Rajasthan, INDIA.

Mobile no: +91 8764279880

Email: drgunjanpragyakumawat@gmail. com

\section{History}

- Submission Date: 02-04-2020

- Revised Date: 10-05-2020

- Accepted Date: 16-07-2020

DOI : 10.5530/ijmedph.2020.3.20

Article Available online

http://www.ijmedph.org/v10/i3

\section{Copyright}

(C) 2020 Phcog.Net. This is an openaccess article distributed under the terms of the Creative Commons Attribution 4.0 International license.

\begin{abstract}
Introduction: ASHA, the grass root level worker is a bridge between population and health system. Objectives: To determine the challenges and hurdles faced by ASHA during their field work in rural area of district Jaipur, Rajasthan. Methods and Materials: A field based descriptive, observational study was conducted among 135 ASHA's of ten PHC's of two blocks of Jaipur, Rajasthan from September 2018 to April 2019 by using a pretested, semi structured questionnaire for socio-economic profile of ASHA and in-depth interview to find out challenges faced by ASHAs during their field work. Results: Majority of ASHA's (67\%) were in the age group of 25-35 yrs, there were six (4\%) young ASHAs who were 25 yrs of age. Majorities ASHA were studied up to secondary (32\%) and higher secondary (28\%), around $20 \%$ were only eighth passed (i.e. minimum education criteria) and (few) seven percentages were graduated. Majorities (84\%) of ASHA were satisfied with their work but experience few challenges in field work however $15 \%$ ASHA are totally satisfied with their job and found none challenges in field work. Conclusion: Multiple inter related factors affects work performance of ASHAs in field. Financial incentives, self-identity and working for society were motivation for joining this profession. However, delayed and inadequate payment, overburden of work, poor transport and conflict between ICDS and Health staff were common challenges.
\end{abstract}

Key words: ASHA, Challenges, Work Performance, Fieldwork, NRHM.

\section{INTRODUCTION}

ASHA, the grass root level worker is a bridge between population and health system. ${ }^{1}$ She has become working as a fundamental unit of health system after its introduction in 2005 by NRHM. ${ }^{2}$ ASHA has to coordinate with AWWs, support ICDS activities and mother and child health care activities. ASHA, being a local resident has increase opportunity to work efficiently and support ICDS and health activities. $^{3}$ India is a country with socio-economic and political diversity; hence diverse challenges in field area expected. Recent some studies have been done to evaluate ASHA's work performance on the basis of socio-demographic variables and work area However there were very few studies focusing on field challenges and hurdles faced by ASHA. Hence this study has been conducted with objectives to determine the challenges and hurdles faced by ASHA during their field work in rural area of district Jaipur, Rajasthan.

\section{MATERIALS AND METHODS}

The present field based descriptive, observational study was conducted in Jamwaramgarh and Chaksu blocks of District Jaipur during September 2018 to April 2019.There were 16 blocks in district Jaipur. In first stage two blocks were randomly selected using simple random sampling technique (SRS). Thereafter, five PHC from each block were randomly selected. There were total 140 ASHAs working in 10 selected PHC's. Out of them one denied to give consent and four ASHA were on maternity leave during study period. Hence 135 ASHAs were included in the study. A pretested, semi structured Preform was used for socio-economic profile of ASHA and indepth interview was conducted to find out challenges faced by ASHAs during their field work. Broadly Average timing for in depth interview was 35-45 min. A modified BJ PRASAD criterion was used to classify socio-economic classes of ASHAs. ${ }^{4}$ Data were collected and analyzed by Microsoft excel. Count data was expressed in percentage.

\section{RESULTS}

All of them were Hindu and were equally distributed in all caste strata i.e. OBC (34\%), general caste (30\%), scheduled tribe and scheduled caste (36\%). All of them were married and two were widow. Majorities (67\%) were in the age group of 25-35 yrs, there were six (4\%) young ASHAs (less than 25 year) who didn't even fulfill government age Criteria. Majority (53\%) ASHA were from middle class, followed by lower middle class (21\%). 20\% ASHAs were from BPL families, only seven percentage were from upper middle class. Majorities ASHA were studied 
up to secondary (32\%) and higher secondary (28\%), around $20 \%$ were only $8^{\text {th }}$ passed (i.e. minimum education criteria) and (few) seven percentages were graduated (Table 1). Post of AWW was lying vacant in one Anganwadi center and post of Auxiliary Nurse Midwife (ANM) was lying vacant in eight anganwadi center. Majorities (84\%) of ASHA were satisfied with their work but experience few challenges in field work however 15\% ASHA are totally satisfied with their job and found none challenges in field work.

\section{Challenges}

Majority (60\%) ASHAs joined for financial incentive and wanted to support family. Around 40\% ASHA stated that reputed image of health worker in society is also a motivating/inspirational factor for joining. There were around $20 \%$ of ASHA (30) who didn't want to join but because of family pressure they have finally joined. Few (7\%) ASHA joined hoping to get permanent employment in health sector in future (Table 2) Timely payment and inadequate incentive was the biggest challenge faced by ASHA and Second issue was to work in coordination with two department activities i.e. ICDS and health and medical department. They have stated that they have joined as ASHA to support their family but now neither they are getting enough incentive nor time for their family as work load is getting heavier day by day. ASHA is expected to help AWW to implement ICDS activities at Anganwadi centre hence AWW supports is equally important in ASHA work performance. Out of all anganwadi workers, ten of them are not cooperative in their work because of conflict arise between working pattern of ICDS activities and medical and health department's activities. Almost half of ASHA (65) reported that both departments want to get their work done on time but none of them wants to cooperate regarding deadline or in field work. Majority (94\%) of ASHA gets priority in OPD during hospital visit. Almost all ASHA (97\%) reported positive support and coordination from medical officer at PHC and they find it encouraging. Some of ASHA (31\%) stated that their work needs extensive travelling i.e. house to house visit, hospital visit with patient, online entry of data in software etc. Travelling also increase due to uneven distribution of population (e.g. Hamlet or cluster). This is discouraging factor for their smooth field work (Table 3). Transport was one of the major issues for $22 \%$ of ASHA. All ASHA's has stated that they have good coordination from Panchayat and panchayat has helped them to create awareness of hygiene, cleanliness and sanitation national program in village and to motivate villagers to construct toilet in their house but 55\% reported that cooperation of Panchayat is very less in motivating of people for population control programs (Table 3).

\section{DISCUSSION}

In present study $47 \%$ of ASHA were less than 30 year, similar to Srivastava et al. ${ }^{5}$ study and Meena $S$ et al. ${ }^{6}$ study. Majority of ASHA (67\%) were in the age group of 25-35 age, that is in synch with Kumar S et al. ${ }^{7}$ study (84\%) but unlike Jain $\mathrm{N}$ et al. ${ }^{8}$ study (40\%). Few (4\%) of them were even below the minimum age criteria of 25 years (as per NRHM guidelines) which is similar to Meena $S$ et al. ${ }^{6}$ study (5\%) but considerably lower than Srivastava et al. ${ }^{5}(25 \%)$ and Saxena et al. ${ }^{9}$ (23\%). Almost all ASHAs were married in present study, similar to Srivastava et al. ${ }^{5}$ Meena $S$ et al. ${ }^{6}$ and Jain $\mathrm{N}$ et al. ${ }^{8}$ studies where more than $90 \%$ ASHAs were married. The present study revealed that issues related to supervision, job security, incentives, poor transport were major challenges in field; similar was reported by sharma et al. ${ }^{10}$ study and by various other studies. ${ }^{11-15}$ Our study revealed that over burden of work assigned by multiple department triggers conflicts between authorities especially of DWCD and medical and health department. Another common obstacle was transport related issues (distance from residence, from health facility and uneven distribution of population). Frequent Inter departmental meeting,

Table 1: Distribution of ASHA as per socio-economic characteristic.
\[ \begin{array}{ccc}\mathrm{n}=135 & \\ \text { Age } & \text { (N) } & \text { Percentage (\%) } \\ <25 & 6 & 4.44 \\ 25-30 & 57 & 42.22 \\ 31-35 & 34 & 25.18 \\ >35 & 38 & 28.14\end{array} \]

$\begin{array}{ccc}\text { Education } & & \\ \text { Up to Eighth } & 26 & 19.25 \\ \text { Up to secondary } & 44 & 32.59 \\ \text { Up to sr. Secondary } & 37 & 27.4 \\ \text { Graduation Or More } & 28 & 20.74 \\ & & \\ \text { Caste } & & 30.37 \\ \text { General } & 41 & 34.07 \\ \text { OBC } & 46 & 22.96 \\ \text { ST } & 31 & 12.59 \\ \text { SC } & 17 & \end{array}$

Economic Status

$\begin{array}{lcc}\text { APL } & 108 & 80 \\ \text { BPL } & 27 & 20\end{array}$

Socio-economic status*

Upper Middle Class

$21 \quad 15.55$

Middle Class

71

52.59

Lower Middle Class

33

24.44

Lower Class

10

7.4

Religion

Hindu

135

100

Others

0

0

Marital Status

Married

133

98.52

Widow

2

1.48

Unmarried

0

0

*updated 2017 BG Prasad socio-economic classification.

\begin{tabular}{cccc|}
\multicolumn{3}{l}{ Table 2: Motivation Factors for ASHA. } \\
S.no & Motivating factors & N $\left({ }^{*}\right)$ & Percentage \% \\
\hline 1. & Financial incentive & 82 & 60.74 \\
2. & Working for society & 57 & 42.22 \\
3. & Self-identity & 50 & 37.03 \\
4. & Family pressure & 30 & 22.22 \\
5. & Seeking permanent employment in & 9 & 6.66 \\
& future
\end{tabular}

${ }^{*}$ Multiple responses from ASHA hence total are more than numbers of ASHAs. 


\begin{tabular}{|c|c|c|c|}
\hline S.N. & Challenges & N & Percentage $\%$ \\
\hline 1. & $\begin{array}{l}\text { Delayed and inadequate } \\
\text { incentive }\end{array}$ & $52^{*}$ & 38.51 \\
\hline 2. & $\begin{array}{l}\text { Overburden of work by multiple } \\
\text { departments }\end{array}$ & $34^{*}$ & 25.18 \\
\hline 3. & $\begin{array}{c}\text { Poor transport facility in field } \\
\text { area }\end{array}$ & $31^{*}$ & 22.96 \\
\hline 4. & $\begin{array}{c}\text { Conflict between DWCD and } \\
\text { health department }\end{array}$ & $31^{*}$ & 22.96 \\
\hline 5. & Non cooperative hospital staff & 4 & 2.96 \\
\hline 6. & $\begin{array}{l}\text { No priority by PHC staff for the } \\
\text { cases referred by ASHA }\end{array}$ & 1 & .74 \\
\hline 7. & None & 20 & 14.81 \\
\hline
\end{tabular}

${ }^{*}$ Multiple responses from ASHA hence total are more than numbers of ASHAs

setting up of committee by Government of India to resolve this affiliation of ASHA issue. Clarity of role and responsibility (job description) of ASHA is mandatory to improve ASHA performance and provide them a friendly working environment.

\section{CONCLUSION}

Multiple inter related factors affects work performance of ASHAs in field. Financial incentives, self-identity and working for society were motivation for joining this profession. However, delayed and inadequate payment, overburden of work, poor transport and conflict between ICDS and Health staff were common challenges.

\section{ACKNOWLEDGEMENT}

Medical officer incharge of Community Health Centre Naila, Jaipur.

\section{CONFLICT OF INTEREST}

The authors declared that they have no conflicts of interest.

\section{ABBREVIATIONS}

ASHA: Accrideted Social Health Activist; NRHM: National Rural Health Mission; AWW: Aanganwadi Worker; ICDS: Integrated Child Development Services; PHC: Primary Health Centre; OBC: Other
Backward Caste; SC: Schedule Caste; BPL: Below Poverty Line; ANM: Auxillary Nurse Midwife; OPD: Outpatient Department.

\section{REFERENCES}

1. Department of health and family welfare, ministry of health and family welfare, Government of India, Annual report, New Delhi. 2016-2017;2:13.

2. Ministry of health and family welfare, National health mission. New Delhi. 2019 http://nhm.gov.in/communitisation/ASHA/about-ASHA.html.

3. Bajpai N, Dholakia RH. Improving the performance of Accredited Social Health Activists in India. Columbia Global Centers. South Asia, Columbia University. 2011.

4. Singh T, Sharma S, Nagesh S. Socio-economic status scales updated for 2017 Int J Res Med Sci. 2017;5(7):3264-7.

5. Srivatava DK, Prakash S, Adhish V, Nair KS, Gupta S, Nandan D. A study of interference of ASHA with the community and the services providers in eastern Uttar Pradesh. Indian Journal of Public Health. 2009;53(3):133-6.

6. Meena S, Rathore M, Singh A, Verma M. Association of Biosocial Profile and Work Performance of Accredited Social Health Activist in Jaipur District. RUHS Journal of Health Sciences. 2019;4(1):18-23.

7. Kumar S, Kaushik A, Kansal S. Factors influencing the work performance of ASHA under NRHM- A cross sectional study from eastern Uttar Pradesh. Indian Journal of Community Health. 2012;24(4):325-31.

8. Jain N, Srivastava NK, Khan AM, Dhar N, Manon S, Adhish V, et al. Assessment of functioning of ASHA under NRHM in Uttar Pradesh. Health and Population: Perspectives and Issues. 2008:31(2):132-40.

9. Saxena V, Kakkar R, Semwal VD. A study on ASHA: A change agent of the society. Indian Journal of Community Health. 2012;24(1):15-8.

10. Sharma R, Webster P, Bhattacharyya $S$. Factors affecting the performance of community health workers in India: A multi-stakeholder perspective. Glob Health Action. 2014;7(1):25352.

11. Guha I, Raut AV, Maliye CH, Mehendale AM, Garg BS. Qualitative Assessment of Accredited Social Health Activists (ASHA) regarding their roles and responsibilities and factors influencing their performance in selected villages of Wardha. Int J Adv Med Health Res. 2018;5(1):21-6.

12. Garg PK, Bhardwaj A, Singh A, Ahluwalia SK. An evaluation of ASHA worker's awareness and practice of their responsibilities in rural Haryana. Natl J Community Med. 2013;4(1):7680.

13. Singh MK, Singh JV, Ahmad N, Kumari R, Khanna A. Factors influencing utilization of ASHA services under NRHM in relation to maternal health in rural Lucknow. Indian J Community Med. 2010;35(3):414-9.

14. Nandan D, Bhatnagar R, Singh K. National Institute of Health and Family Welfare and UNFPA. Assessment of performance based incentive system for ASHA Sahyogini in Udaipur District, Rajasthan. 2009. Available from: http://www.nihfw. org/pdf/RAHI-II Reports/UDAIPUR.pdf [cited 11 August 2014].

15. Martin A, Almas S, Brown W, Sahni HV, Serotta R. Knowledge Community on Childrenin India (KCCl). Effect of Supportive Supervision on ASHAs' Performance under IMNCl in Rajasthan. 2009;1-75. Available from: http://www.kcci. org.in/Document Repository/08 ASHA IMNCIRajasthan.pdf 